\title{
COUPLED NITROGEN AND OXYGEN ISOTOPE STUDY OF NITRATE AT A RURAL UNLINED LANDFILL IN WESTERN VICTORIA, AUSTRALIA
}

\author{
John W. Moreau and Andrew M. Minard \\ School of Earth Sciences, University of Melbourne, Parkville, VIC 3010, Australia
}

Received 2013-09-30; Revised 2014-06-13; Accepted 2014-06-30

\begin{abstract}
Understanding of site-scale physical and chemical heterogeneities will inform remediation strategies for unlined rural landfills worldwide. The aim of this study was to characterize potential sources of nitrogen contamination to groundwater at an unlined landfill in rural western Victoria, Australia. Results revealed simultaneously high concentrations of both nitrate and ammonia within several wells, indicative of heterogeneous redox potentials within the unconfined aquifer. Combined isotopic analyses of $\delta^{15} \mathrm{~N}$ and $\delta^{18} \mathrm{O}$ in nitrate identified a leachate-derived source and active denitrification across two sites hydraulically downgradient from the landfill cell. Groundwater at an up-gradient site, as well as nearby surface water samples from a riparian creek, reflected primarily the isotopic signature of agriculturally-derived nitrate with overprinting from atmospheric exchanges of nitrogen and oxygen. Nitrate and ammonia in the creek were interpreted to result from a mixture of leachate and agricultural sources. Results illustrate how redox gradients across a landfill leachate plume impact biogeochemical nitrogen cycling.
\end{abstract}

Keywords: Landfill Leachate, Redox Gradient, Nitrogen Isotopes, Denitrification, Groundwater Contamination

\section{INTRODUCTION}

Effective remediation of groundwater contamination by leachate from unlined (and possibly decommissioned) landfill sites requires site-scale hydrogeological characterization (Tiller, 1992; McLay et al., 2001; Allen, 2001). Groundwater flow direction and chemistry can influence the mobility and fate of leachate contaminants (Poeter and Gaylord, 1990; Assmuth and Strandberg, 1994). Variations in hydraulic conductivity in a sedimentary aquifer, e.g., due to changes in lithology (Genereux and Guardiario, 2010), can induce redox gradients that control the distribution of microbial consortia and thus the potential for contaminant biodegradation (Bjerg and Christensen, 1992; Jankowski and Beck, 2000). Understanding of site-scale physical and chemical heterogeneities is therefore important for effectively harnessing microbial activity for bioremediation (Cozzarelli et al., 2011), particularly at unlined rural landfills, a common historical type of landfill worldwide (e.g., USGS, 2003). Of particular interest is how nitrogen-bearing contaminants (i.e., nitrate or ammonia) can be transported or transformed via a number of physical and biogeochemical pathways. Various approaches exist for understanding the distribution of potential electron donors for denitrification in leachate plumes (Cozzarelli et al., 2000).

This study investigated the origin and distribution of nitrate and ammonia in groundwater receiving leachate from a rural unlined landfill site in western-central Victoria, Australia. The lack of published data on contaminated rural unlined Australian landfills (WCS, 2010) was a primary motivator for this study and the field site for this study provided a typical example of an unlined rural Australian landfill with irregular historical waste collection records. The site is located in a region of Victoria where agricultural nitrate contamination of groundwater was historically of concern and is adjacent to a protected riparian zone. Our study focused on understanding the distribution and type of nitrogen

Corresponding Author: John W. Moreau, School of Earth Sciences, University of Melbourne, Parkville, VIC 3010, Australia 
species within the unconfined aquifer receiving leachate from the landfill cell. Based on previous studies at other sites (Cozzarelli et al., 2011) and the lithological heterogeneity of the unconfined aquifer reported in core logs, we hypothesized that nitrogen redox transformations may vary considerably throughout the leachate plume. Although many studies have been conducted of nitrate contamination of groundwater by agricultural or waste water sources, as expressed in coupled nitrogen and oxygen isotope ratios (in nitrate), a paucity of data exists for rural unlined landfills. Here we applied field-based spectrophotometry of redox-sensitive chemical species and coupled nitrogen and oxygen isotope ratio analyses of nitrate in groundwater, to differentiate potential nitrate sources and delineate the extent of denitrification associated with a rural unlined Australian landfill.

\section{MATERIALS AND METHODS}

The Beaufort Transfer Station (BTS) is a rural landfill in western-central Victoria (Fig. 1) that lacks a liner and leachate collection system. The landfill cell sits approximately 4-5 meters in topographic elevation above the surrounding flood terrace sedimentary deposits to the northeast and is thought to be approximately 6-7 meters in depth, although the accuracy of historical records has been questioned. The landfill therefore essentially slopes downward towards the northeast across the scale of the entire site.

Investigations were conducted at the BTS in 20092010; groundwater samples were collected from three usable boreholes (MB01, MB02 and MB04), which penetrated the unconfined aquifer to shallow depths of 3, 4.5 and 4.5 meters, respectively (Fig. 2). Screens for these bores were $1.5,3$ and 3 meters long, respectively and opened to mainly clay and silt (MB01, MB04) or sands and paleo-stream gravels (MB02). Borehole MB03 was partially collapsed and could not be used. A single borehole penetrating to an unknown depth and with an unknown screen length within the landfill cell was sampled as well, although this well was considered, by visual inspection, to be poorly installed and maintained. This well consisted of a simple PVC pipe casing with no cap, no apparent annular seal or well packing of any kind and no sealing of the borehole at the surface, compared to properly installed wells at MB01, MB02 and MB04.

Historical standing water level data for the wells (Supplementary Fig. 3) show that the general groundwater flow direction is from MB04, located up-gradient hydraulically of the landfill cell, towards MB02 and MB01 either due northward or northeastward, depending on seasonal or annual recharge rates. Samples were collected with a bailer, after purging of two well volumes. Boreholes were not purged dry in order to prevent interference of field spectrophotometric assays by turbidity. Bailers were rinsed with decontaminant solution and ultrapure (Milli-Q) water on site before use.

Groundwater and surface water chemistry measurements (pH, EC, alkalinity and Eh) were obtained in the field (Fig. 4 and Table 1). Three-point calibration was used on an Orion 5-Star meter with automatic temperature correction for $\mathrm{pH}$ and $\mathrm{EC}$; Eh was measured using an Orion 250A meter and redox probe and values were corrected to the standard hydrogen electrode. Total alkalinity (calculated as $\mathrm{mg} / \mathrm{L}$ of $\mathrm{CaCO}_{3}$ ) was measured using a $\mathrm{HACH}$ digital titrator with $100 \mathrm{ml}$ of groundwater or surface water titrated using $0.16 \mathrm{~N}$ sulphuric-acid to a $\mathrm{pH}$ value of 4.35 using the inflection endpoint method. All groundwater or surface water samples were filtered through a $0.45 \mu \mathrm{m}$ pore-size filter, with groundwater samples for cations and trace metals acidified with trace metal grade $\mathrm{HNO}_{3}$ to a $\mathrm{pH}<2$. Sulfate, nitrate, chloride, nitrite and ammonia were measured using a DR2800 $\mathrm{HACH}$ Spectrophotometer in the field and in the lab. Nitrate, ammonia and nitrite analyses were conducted on site using the appropriate colorimetric assays for both groundwater and surface waters. Each assay was analyzed with a reference standard matrix designed to correct for $\mathrm{Cl}^{-}$ $\left(>1000 \mathrm{mg} \mathrm{L}^{-1}\right)$ in the groundwater. Major cations and trace metals were analyzed using ICP-AES (ALS Laboratory Group, Springvale, VIC, Australia) and major anions were analyzed using IC at the Australian National University. Sampling bottles were rinsed with filtered sample water before sample collection. Field blanks were used to quantify any contamination during sample handling and transport.

Sampling and processing of groundwater and surface waters for $\delta^{15} \mathrm{~N}$ and $\delta^{18} \mathrm{O}$ followed the protocol of the Colorado Plateau Stable Isotope Laboratory (CPSIL; Flagstaff, AZ, USA) (Sigman et al., 2001). Analyses were performed using the Gas Bench Precon isotope ratio mass spectrometer (GB-Precon IRMS). Samples were collected in triplicate in acid-washed Nalgene bottles that were triple-rinsed with nanopure (Milli-Q) water. Two sets of triplicates were collected for each sampling site; one set of $100 \mathrm{ml}$ each for total nitrate concentration and the other set of $100 \mathrm{ml}$ each for isotopic analysis. Each sample was filtered in the field with $0.22 \mu \mathrm{m}$ pore-size filters and immediately placed on ice. 

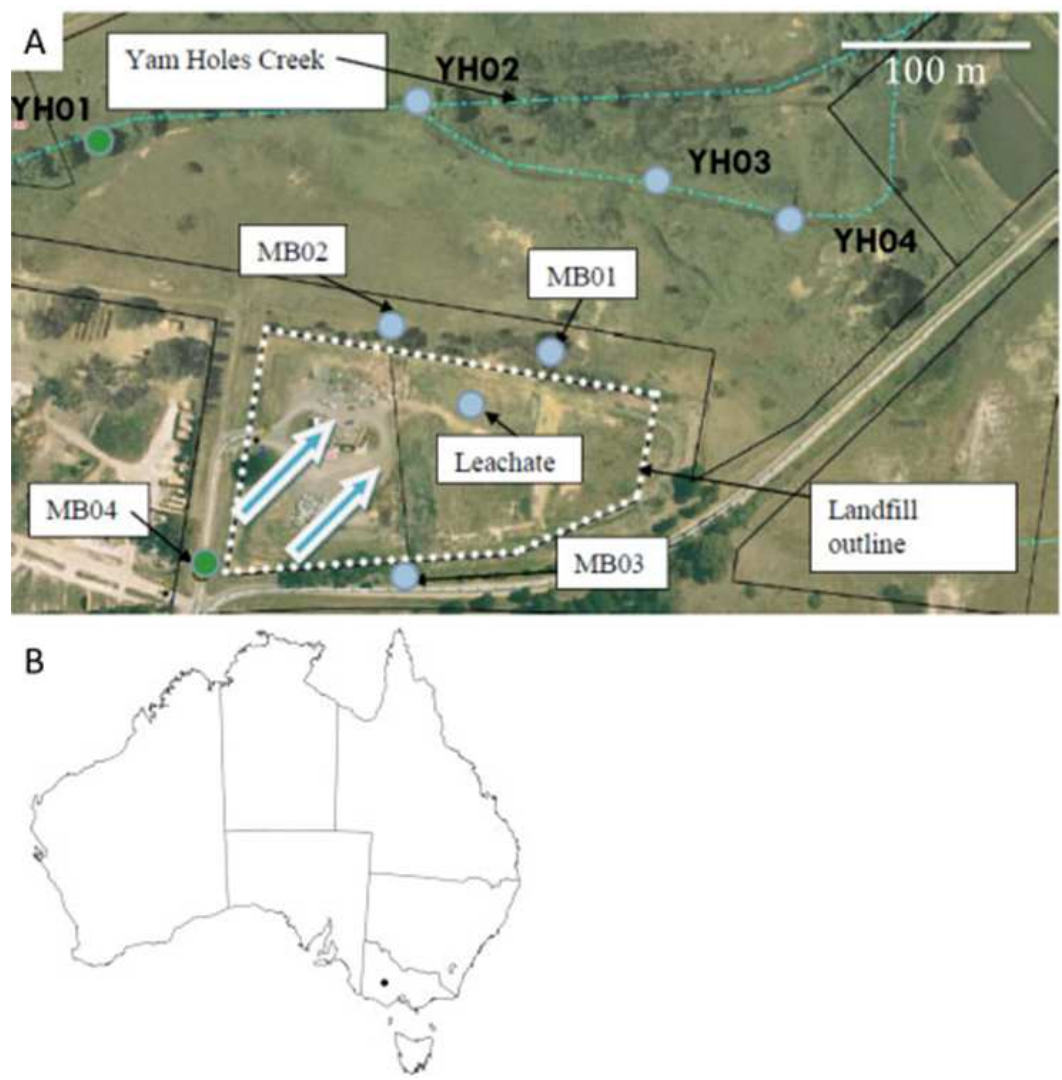

Fig. 1. Beaufort Transfer Station landfill site. (A) Boreholes MB01-MB04 and a leachate borehole are shown in white boxes (MB03 was damaged and decommissioned in2003). Yam Holes Creek surface sampling sites YH01-YH04 are shown in bold black font. Dotted line describes landfill boundary. North is to the top of the image. (B) Line drawing map of Australia with location of Beaufort as filled circle

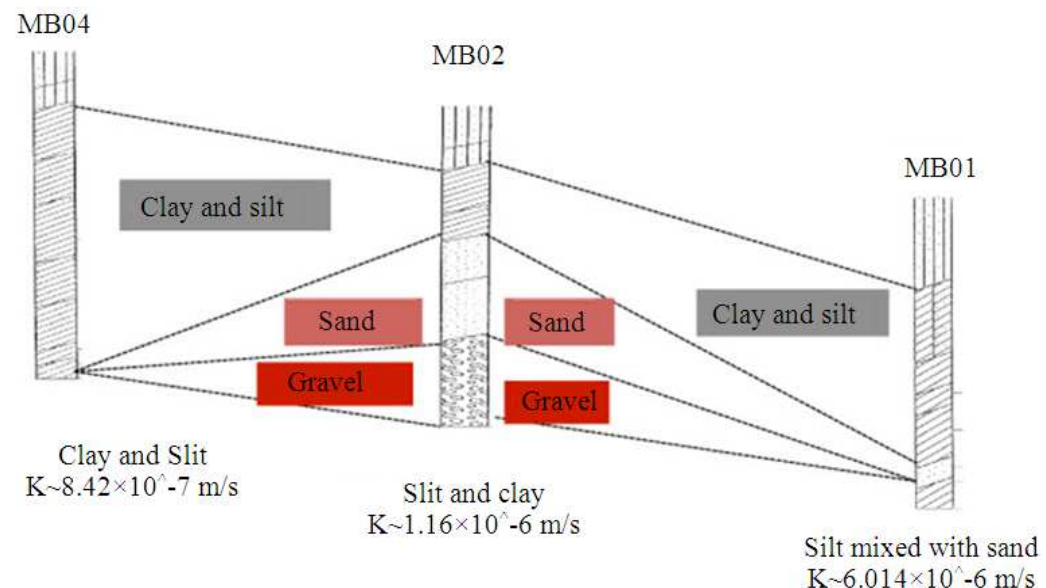

Fig. 2. Simplified cross-section of unconfined aquifer at BTS landfill. Monitoring bore locations MB01, MB02 and MB04 are shown schematically and with relative elevations (not to scale). Hydraulic conductivity estimates are based on historical slug test results (data not shown) 
John W. Moreau and Andrew M. Minard / American Journal of Environmental Sciences 10 (4): 383-390, 2014

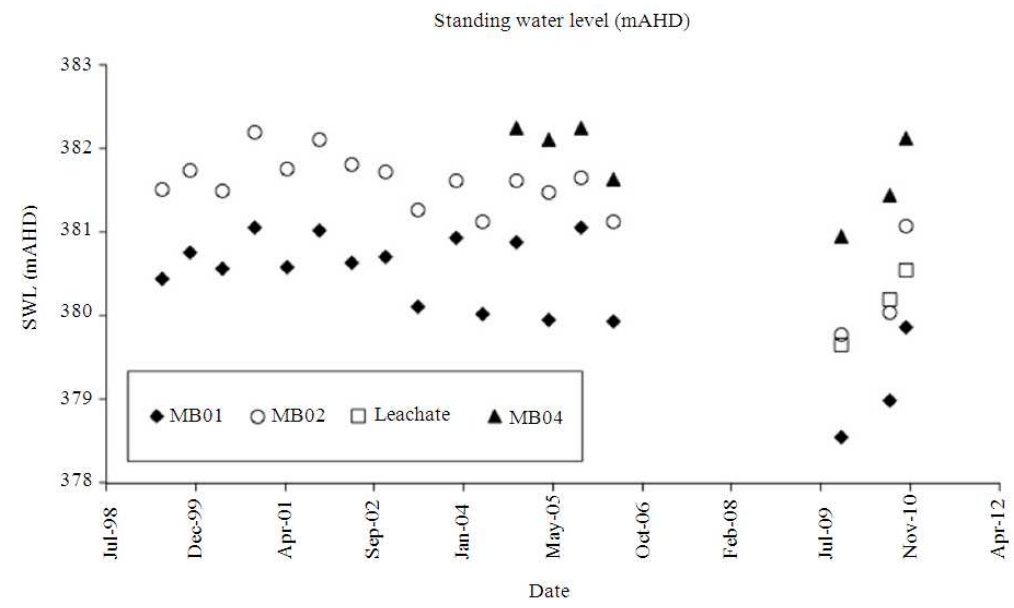

Fig. 3. Historical and recent standing water level data (mAHD) for wells MB01, MB02, MB04 and the landfill leachate sampling bore (located within the landfill cell) at the Beaufort Transfer Station landfill

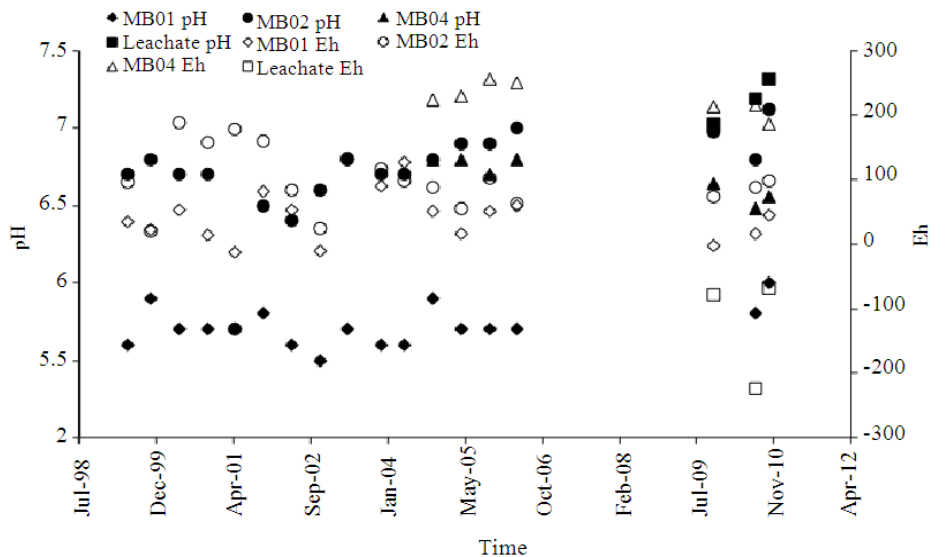

(a) ${ }^{\text {Time }}$

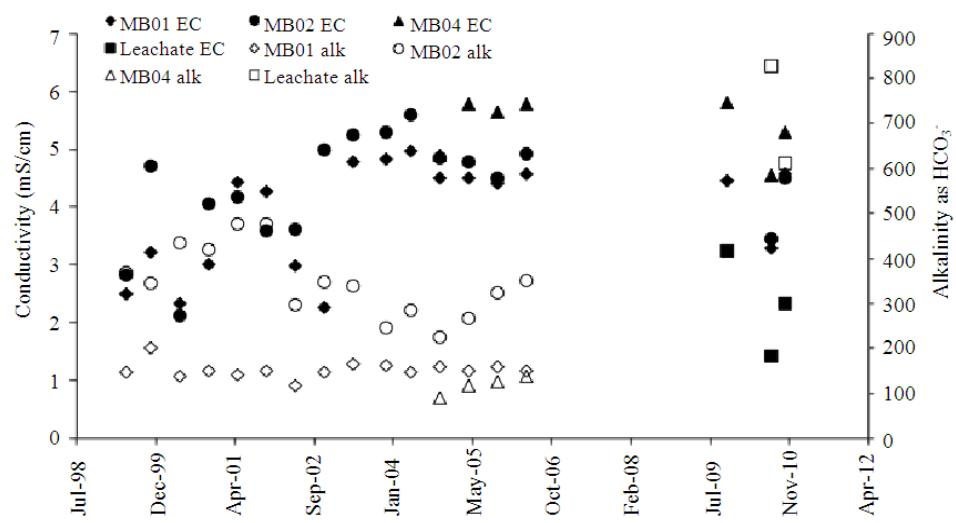

(b)

Fig. 4. Historical and recent hydrogeochemical field measurements at the BTS landfill site. (A) pH and Eh measurements, (B) conductivity and alkalinity measurements. See Methods section for information on field sampling and measurement protocols Samples were transferred back to the lab within $\sim 3$ hours upon collection and were immediately frozen at $-20^{\circ} \mathrm{C}$. Samples were shipped the next day in a Styrofoam container with ice packs and received at CPSIL within two days 
John W. Moreau and Andrew M. Minard / American Journal of Environmental Sciences 10 (4): 383-390, 2014

Table 1. Major ions and trace metals concentrations (in mg/L) from BTS monitoring wells sampled in July 2010.

\begin{tabular}{lllllllllllll}
\hline Borehole & $\mathrm{Ca}$ & $\mathrm{Fe}$ & $\mathrm{K}$ & $\mathrm{Mg}$ & $\mathrm{Mn}$ & $\mathrm{Na}$ & $\mathrm{F}$ & $\mathrm{Cl}$ & $\mathrm{NO} 3$ & $\mathrm{PO} 4$ & $\mathrm{NH3}$ & $\mathrm{SO} 4$ \\
\hline MB04 & 51 & 0.02 & 13 & 140 & 1.6 & 950 & 0.17 & 1420 & 12 & bdl & 0.3 & 40 \\
Leachate & 61 & 2.5 & 39 & 120 & 0.73 & 650 & 0.39 & 240 & 34 & bdl & 0.4 & 7 \\
MB02 & 60 & 0.65 & 44 & 120 & 2.3 & 650 & 0.2 & 870 & 20 & bdl & 0.4 & 28 \\
MB01 & 93 & 0.48 & 43 & 43 & 0.09 & 550 & 0.2 & 840 & 1.1 & bdl & bdl & 27 \\
Borehole & $\mathrm{As}$ & $\mathrm{Cd}$ & $\mathrm{Cr}$ & $\mathrm{Co}$ & $\mathrm{Cu}$ & $\mathrm{Pb}$ & $\mathrm{Ni}$ & $\mathrm{Zn}$ & $\mathrm{Sr}$ & $\mathrm{Al}$ & $\mathrm{Sr}$ & $\mathrm{Si}$ \\
MB04 & 0.002 & 0.0003 & $\mathrm{bdl}$ & 0.004 & $\mathrm{bdl}$ & $\mathrm{bdl}$ & 0.002 & 0.008 & 0.34 & bdl & 8 & \\
Leachate & bdl & bdl & 0.057 & 0.030 & 0.004 & $\mathrm{bdl}$ & 0.006 & 0.006 & 0.4 & bdl & 9 & \\
MB02 & bdl & bdl & bdl & bdl & 0.032 & bdl & 0.006 & 0.010 & 0.42 & bdl & 8 & \\
MB01 & 0.006 & 1.2 & 0.003 & 0.088 & 0.025 & bdl & 0.09 & 1.6 & 0.42 & bdl & 7 & \\
\hline
\end{tabular}

\section{RESULTS}

Groundwater field parameters (Fig. 4) showed that $\mathrm{pH}$ remained consistent over sampling timescales, while redox potential (Eh) exhibited variability across the landfill with the most oxidized conditions $(\sim 200 \mathrm{mV})$ found up-gradient hydraulically of the landfill cell in MB04. MB01 and MB02 showed redox potentials of $\sim 0$ $\mathrm{mV}$ and $\sim 100 \mathrm{mV}$ respectively. Groundwater EC values were generally brackish, ranging from 1-6 mS/cm, with the highest and lowest EC values observed during the wet and dry months, respectively. EC in groundwater varied across the BTS site with the highest values in MB04 ( 5.67 mS cm $\left.\mathrm{cm}^{-1}\right)$. Groundwater showed a decreasing trend in EC from MB04 to MB01 ( 3.88 $\mathrm{mS} / \mathrm{cm})$ and $\mathrm{MB} 02\left(\sim 4.38 \mathrm{mS} \mathrm{cm}^{-1}\right)$. Alkalinity as
$\mathrm{HCO}_{3}{ }^{-}$showed higher values in MB02 $\left(\sim 355 \mathrm{mg} \mathrm{L}^{-1}\right)$, compared to MB01 ( 128 $\left.\mathrm{mg} \mathrm{L}^{-1}\right)$ and MB04 ( 92 mg $\left.\mathrm{L}^{-1}\right)$. Table 1 shows that borehole MB04 showed moderate nitrate concentrations $\left(0.03-0.565 \mathrm{mg} \mathrm{L}^{-1}\right)$ and high ammonia $\left(0.16 \mathrm{mg} \mathrm{L}^{-1}\right.$ to $\left.0.525 \mathrm{mg} \mathrm{L}^{-1}\right)$, while MB01 exhibited low nitrate $\left(0.01 \mathrm{mg} \mathrm{L}^{-1}\right.$ to $\left.0.05 \mathrm{mg} \mathrm{L}^{-1}\right)$ and ammonia concentrations $(0.01 \mathrm{mg}$ $\mathrm{L}^{-1}$ to $\left.0.1 \mathrm{mg} \mathrm{L}^{-1}\right)$. In contrast, MB02 exhibited high $\mathrm{NO}_{3}^{-}\left(4 \mathrm{mg} \mathrm{L}{ }^{-1}\right.$ to $\left.6 \mathrm{mg} \mathrm{L}^{-1}\right)$ and ammonia $(0.036 \mathrm{mg}$ $\mathrm{L}^{-1}$ to $4.87 \mathrm{mg} \mathrm{L}^{-1}$ ).

Groundwater sampled from within the landfill cell showed the highest concentrations of dissolved iron and nitrate ( 2.5 and $34 \mathrm{mg} \mathrm{L}^{-1}$, respectively), but the lowest concentrations of chloride and sulfate $(240$ and $7 \quad \mathrm{mg} \quad \mathrm{L}^{-1}, \quad$ respectively).

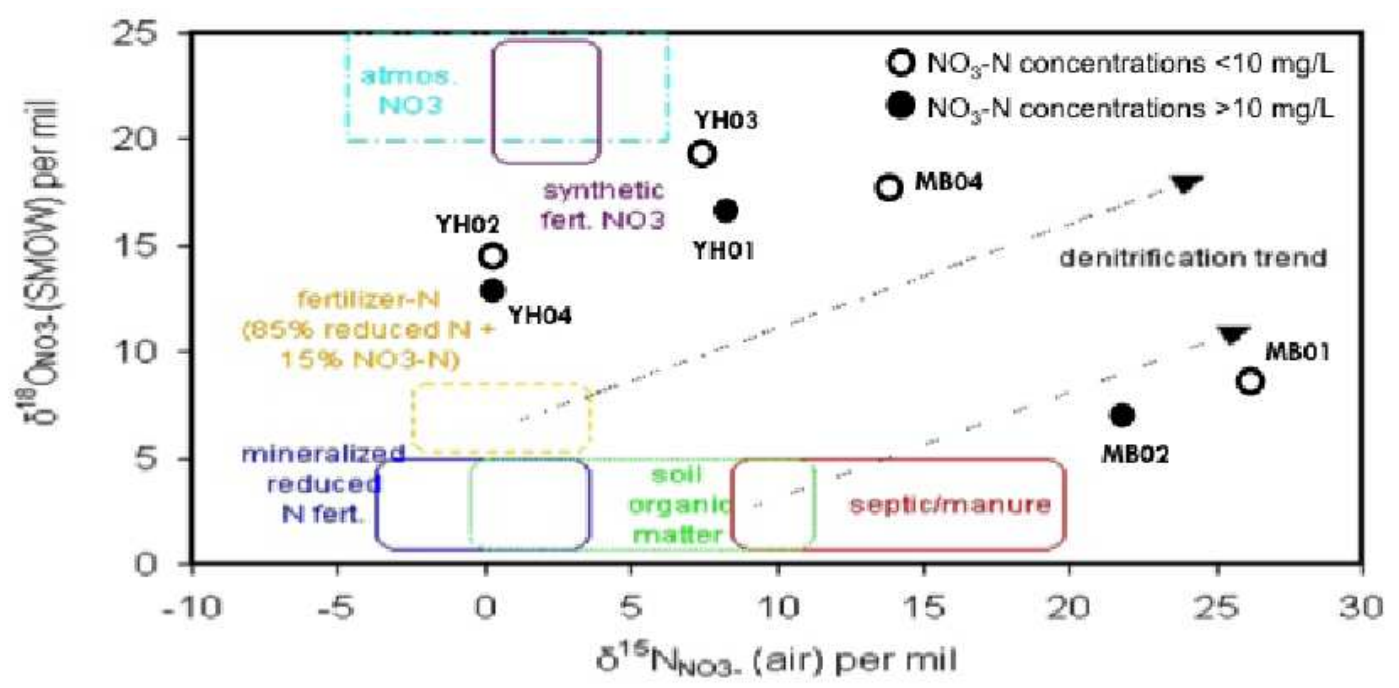

Fig. 4. Plot of nitrogen and oxygen isotope ratios in nitrate sampled from monitoring wells at BTS landfill and nearby Yam Holes Creek sites. Data are superimposed on the schematic figure from (Clark and Fritz, 1997) 
Surface water samples along the Yam Holes Creek showed a substantial variation along its long profile. Background surface water (YH01) had moderate nitrate concentrations $(1.9 \mathrm{mg} / \mathrm{L})$ and low concentrations of ammonia $(.01 \mathrm{mg} / \mathrm{L})$ and $\mathrm{HCO}_{3}^{-}(93 \mathrm{mg} / \mathrm{L})$. Surface water sites closer to the BTS, however, at YH02 and YH04 exhibited $\mathrm{NO}_{3}{ }^{-}$concentrations above freshwater guidelines $(10.4 \mathrm{mg} / \mathrm{L}$ and $10.9 \mathrm{mg} / \mathrm{L}$ respectively). Still, elevated nitrate concentrations were not consistent along the down- gradient portion of the creek as YH03 showed very low concentrations of nitrate $(.46 \mathrm{mg} / \mathrm{L})$, ammonia $(.04 \mathrm{mg} / \mathrm{L})$ and $\mathrm{HCO}_{3}^{-}(35 \mathrm{mg} / \mathrm{L})$.

Figure 5 shows $\delta^{18} \mathrm{O}$ and $\delta^{15} \mathrm{~N}$ values of nitrate sampled in groundwater and surface waters, plotted alongside typical $\delta^{18} \mathrm{O}$ and $\delta^{15} \mathrm{~N}$ values for various sources of nitrate defined by (Clark and Fritz, 1997). Isotope ratios for MB01 and MB02 were $\delta^{15} \mathrm{~N}=+26 \%$, $\delta^{18} \mathrm{O}=+9 \%_{\mathrm{o}}$ and $\delta^{15} \mathrm{~N}=+22 \%_{\mathrm{o}}, \quad \delta^{18} \mathrm{O}=+6 \%_{\mathrm{o}}$, respectively. Isotope ratios for $\mathrm{MB} 04, \mathrm{YH} 04, \mathrm{YH} 03$, YH02 and YH01 were $\delta^{15} \mathrm{~N}=+14 \%_{0}, \delta^{18} \mathrm{O}=+17 \%_{0}$; $\delta^{15} \mathrm{~N}=+26 \%_{0}, \delta^{18} \mathrm{O}=+9 \%_{0} ; \delta^{15} \mathrm{~N}=+26 \%_{0}, \delta^{18} \mathrm{O}=$ $+9 \%_{0} ; \delta^{15} \mathrm{~N}=+26 \%_{0}, \delta^{18} \mathrm{O}=+9 \%_{0}$; and $\delta^{15} \mathrm{~N}=+26 \%$, $\delta^{18} \mathrm{O}=+9 \%$, respectively. Both groups of wells, MB02 and MB01 and YH01-YH04 with MB04, yielded isotope ratio data that plotted towards increasingly heavier (more positive) isotopic ratios for both nitrogen and oxygen.

\section{DISCUSSION}

The increases in alkalinity and $\mathrm{pH}$, with a decrease in reduction potential (Eh), from MB04 to MB02 or MB01, are all consistent with an input of bicarbonate from microbially-mediated anaerobic degradation of organic matter within the landfill cell (Brad et al., 2008). The presence of both nitrate and ammonia in the leachate bore and MB02 and to some degree in MB04, suggests that high spatial heterogeneity in redox potential of groundwater in the unconfined aquifer was reflected by the chemistry sampled in these wells. In other words, groundwater from wells MB02 and MB04 (setting the leachate bore aside for reasons discussed above) likely represents a mixture of reduced and oxidized nitrogen species from heterogeneous "pockets" of the unconfined aquifer with varying redox potentials that has not yet reacted with atmospheric oxygen within the wells. We infer that groundwater from MB02 and MB04 may reflect the presence of heterogeneous zones of microbial denitrification and ammonia oxidation within the aquifer, presumably separated and mediated by different populations within the aquifer microbial community structure. Also, the presence of paleo-stream gravels with higher hydraulic conductivity in MB02 serves to focus meteoric recharge and locally increase groundwater flow rates, resulting in more oxic conditions, shorter pore water residence times and less chemical potential for complete denitrification.

For detailed discussion of the placement of fields describing the nitrogen and oxygen isotopic compositions of various possible nitrate sources and the changes in these ratios that would result from denitrification, we refer the reader to the original source from which we derived the (modified) Fig. 4 (Clark and Fritz, 1997). Isotopic ratios for wells MB01 $\left(\delta^{15} \mathrm{~N}=\right.$ $\left.+26 \% \%_{0}, \delta^{18} \mathrm{O}=+9 \%_{\mathrm{o}}\right)$ and MB02 $\left(\delta^{15} \mathrm{~N}=+22 \%_{\mathrm{o}}, \delta^{18} \mathrm{O}=\right.$ $+6 \%$ o , located down gradient of the landfill cell, exhibited values associated with manure and/or septic sources of nitrate (Fig. 4). This finding is consistent with the idea that these two wells groundwater contaminated with landfill leachate-derived nitrate and organic compounds. We could not resolve, with the data obtained in this study, a significant difference in the isotopic signatures of landfill leachate-derived and septic-derived nitrate, a result similar to those of (Aravena et al., 1993; Aravena and Robertson, 1998). In contrast, wells MB04 $\left(\delta^{15} \mathrm{~N}=+14 \%_{0}, \quad \delta^{18} \mathrm{O}=+17 \%_{0}\right)$ and surface water sampling sites YH04 $\left(\delta^{15} \mathrm{~N}=+26 \% \%_{0}, \delta^{18} \mathrm{O}=+9 \%\right.$ ), YH03 $\left(\delta^{15} \mathrm{~N}=+26 \% \%_{0}, \delta^{18} \mathrm{O}=+9 \% \%_{0}\right)$, YH02 $\left(\delta^{15} \mathrm{~N}=\right.$ $\left.+26 \% \%_{0}, \delta^{18} \mathrm{O}=+9 \%_{\mathrm{o}}\right)$ and YH01 $\left(\delta^{15} \mathrm{~N}=+26 \% \%_{\mathrm{o}}, \delta^{18} \mathrm{O}=\right.$ $+9 \% \%_{0}$ ), from Yam Holes Creek, all yielded nitrogen and oxygen isotope ratios comparable to fertilizer sources of nitrate and possibly some $\mathrm{O}$ and $\mathrm{N}$ isotopic exchange with the atmosphere that could have occurred during evaporation. The $\delta^{18} \mathrm{O}$ and $\delta^{15} \mathrm{~N}$ values of $\mathrm{MB} 01$ and MB02 contrasted significantly with those of MB04, indicative of a greater degree of contamination from nitrate in landfill leachate at MB01 and MB02. The values of $\delta^{15} \mathrm{~N}$ and $\delta^{18} \mathrm{O}$ observed in our study are comparable to the ranges of these isotope ratios observed in previous studies of septic-contaminated systems (Aravena and Robertson, 1998) (Table 1) with the exception that our $\delta^{18} \mathrm{O}$ ratios possibly reflect greater effects from evaporation.

Linear trends in the isotope ratio data reflect the increasing extent of denitrification detected in both groundwater and surface waters. However, waters from Yam Holes Creek contained the $\mathrm{N}$ and $\mathrm{O}$ isotopic signatures of a different nitrate source from landfill leachate. Therefore, although the YH02 and YH04 sites appear to have elevated nitrate levels more similar to MB02 than to YH01 or YH03, some agriculturally derived nitrate (i.e., from synthetic or natural fertilizer) also contributes to the $\delta^{15} \mathrm{~N}$ and $\delta^{18} \mathrm{O}$ values of surface waters. We hypothesize that 
nitrate contamination from the landfill is being effectively channeled along near-surface $(<5$ meters depth) paleostream channel gravels and has possibly already delivered elevated nitrate levels to portions of Yam Holes Creek. Recent conversion of local blue gum plantations to the north and west of Beaufort to canola farming (http://www.abc.net.au/news/2013-06-05/blue-gum-

demise/4735044), with consequent increased fertilizer requirements (Hocking et al., 1997), may also have contributed to the observed isotope ratios of surface waters. Future research should focus on testing the hypothesis, or further substantiating evidence, that landfill leachatederived nitrate has already impacted the local surface riparian ecosystem in and around Yam Holes Creek.

\section{CONCLUSIONS}

The findings of this study reveal the extent of nitrogen transformations and biogeochemical cycling across a landfill leachate plume in a lithologically heterogeneous and shallow unconfined aquifer. Cooccurrence of nitrate and ammonia in some wells supports the interpretation that significant heterogeneity in redox potential exists, most likely as a result of the degree of lithological variability (i.e., variations in hydraulic conductivity). These lithological variations are primarily the result of buried paleo-stream channels typical of riverine plains across much of the Australian Murray-Darling Basin. Coupled nitrogen and oxygen isotope ratio analyses allowed the resolution of disparate nitrate sources in groundwater impacted by landfill leachate.

\section{ACKNOWLEDGEMENTS}

We thank Brian Myles and Rob Ladd of the Pyrenees Shire Council for access to the Beaufort Transfer Station site and research support, including a postgraduate scholarship to A.M.M. We also thank Gretchen Sites and Emily Hepburn for fieldwork assistance.

\section{REFERENCES}

Allen, A., 2001. Containment landfills: The myth of sustainability. Eng. Geol., 60: 3-19. DOI: 10.1016/S0013-7952(00)00084-3

Aravena, R. and W.D. Robertson, 1998. Use of multiple isotope tracers to evaluate denitrification in ground water: Study of nitrate from a large-flux septic system plume. Ground Water, 36: 975-982. DOI: 10.1111/j.1745-6584.1998.tb02104.x
Aravena, R., M.L. Evans and J.A. Cherry, 1993. Stable isotopes of oxygen and nitrogen in source identification of nitrate from septic systems. Ground Water, 31: 180-186. DOI: 10.1111/j.17456584.1993.tb01809.x

Assmuth, T.W. and T. Strandberg, 1994. Ground water contamination at Finnish landfills. Water, Air Soil Pollut., 69: 179-199. DOI: 10.1007/BF00478358

Bjerg, P.L. and T.H. Christensen, 1992. Spatial and temporal small-scale variation in groundwater quality of a shallow sandy aquifer. J. Hydro., 131: 133-149. DOI: 10.1016/0022-1694(92)90215-H

Brad, T., B.M. Van Breukelen, M. Braster, N.M. Van Straalen and W.F.M. Röling, 2008. Spatial heterogeneity in sediment-associated bacterial and eukaryotic communities in a landfill leachatecontaminated aquifer. FEMS Microbiol. Ecol., 65: 534-543. DOI: 10.1111/j.1574-6941.2008.00533.x

Clark, I. and P. Fritz, 1997. Environmental Isotopes in Hydrogeology, 1st Edn., Illustrated, reprint, CRC Press, ISBN-10: 1566702496, pp: 352.

Cozzarelli, I.M., J.K. Böhlke, J. Masoner, G.N. Breit and M.M. Lorah, et al., 2011. Biogeochemical evolution of a landfill leachate plume, Norman, Oklahoma. Groundwater, 49: 663-687. PMID: 21314684

Cozzarelli, I.M., J.M. Suflita, G.A. Ulrich, S.H. Harris and M.A. Scholl et al., 2000. Geochemical and microbiological methods for evaluating anaerobic processes in an aquifer contaminated by landfill leachate. Environ. Sci. Technol., 34: 4025-4033. DOI: $10.1021 /$ es991342b

Genereux, D.P. and J.D.A. Guardiario, 2001. A borehole flowmeter investigation of small-scale hydraulic conductivity variation in the Biscayne Aquifer, Florida. Water Resource Res., 37: 1511-1517. DOI: 10.1029/2001WR900023

Hocking, P.J., P.J. Randall, D.D. Marco and I. Bamforth, 1997. Assessment of the nitrogen status of fieldgrown canola (Brassica napus) by plant analysis. Australian J. Experimental Agric., 37: 83-92. DOI:10.1071/EA95068

Jankowski, J. and P. Beck, 2000. Aquifer heterogeneity: Hydrogeological and hydrochemical properties of the Botany Sands aquifer and their impact on contaminant transport. Australian J. Earth Sci., 47: 45-64. DOI: 10.1046/j.1440-0952.2000.00768.x

McLay, C.D.A., R. Dragten, G. Sparling and N. Selvarajah, 2001. Predicting groundwater nitrate concentrations in a region of mixed agricultural land use: a comparison of three approaches. Environ. Pollut., 115: 191-204. DOI: 10.1016/S02697491(01)00111-7 
Poeter, E. and D.R. Gaylord, 1990. Influence of aquifer heterogeneity on contaminant transport at the Hanford site. Ground Water, 28: 900-909. DOI: 10.1111/j.1745-6584.1990.tb01726.x

Sigman, D.M., K.L. Casciotti, M. Andreani, C. Barford, M. Galanter and J.K. Böhlke, 2001. A bacterial method for the nitrogen isotopic analysis of nitrate in seawater and freshwater. Analytical Chem., 73: 4145-4153. PMID: 11569803
Tiller, K.G., 1992. Urban soil contamination in Australia. Soil Res., 30: 937-957. DOI: 10.1071/SR9920937

USGS, 2003. Natural science and public health: Prescription for a better environment. pubs.usgs.gov/of/2003/of03-097/

WCS, 2010. Review of the application of landfill standards. Report commissioned the Australian Department of the Environment, Water and Heritage. 